Jurnal Keperawatan Silampari

Volume 4, Nomor 1, Desember 2020

e-ISSN: 2581-1975

p-ISSN: 2597-7482

DOI: https://doi.org/10.31539/jks.v4i1.1626

\title{
PIJAT OKETANI DAN TEKANAN DI TITIK AKUPRESUR GB-21 TERHADAP PRODUKSI ASI PADA IBU POST SECTIO CAESAREA
}

\author{
Putri Permata Sari ${ }^{1}$, Irna Nursanti ${ }^{2}$, Giri Widakdo ${ }^{3}$ \\ Akademi Keperawatan PELNI Jakarta ${ }^{1}$ \\ Universitas Muhammadiyah Jakarta ${ }^{2,3}$ \\ Putriabdpatta92@gmail.com ${ }^{1}$
}

\begin{abstract}
ABSTRAK
Penelitian ini bertujuan untuk mengetahui efektifitas pijat oketani dan tekanan akupresur GB-21 terhadap produksi ASI pada ibu post sectio caesarea. Metode penelitian yang digunakan adalah penelitian kuantitatif dengan rancangan penelitian quasi eksperimental one group pre-posttest design. Hasil penelitian menyebutkan tekanan di titik akupresur GB21 terbukti efektif berdasarkan indikator Ibu dan bayi. Hasil uji statistik menunjukkan bahwa ada perbedaan produksi ASI sebelum dan setelah diberikan tekanan di titik akupresur Gb-12 (p value =0,000). Simpulan, pijat oketani lebih efektif untuk meningkat produksi ASI pada kelompok A ibu post sectio caesarea dibandingkan kelompok B tekanan di titik akupresure $G b-21$ dari indikator bayi.
\end{abstract}

Kata Kunci: Akupresur Gb-21, ASI, Pijat Oketani, Sectio Caesarea

\begin{abstract}
This study aims to determine the effectiveness of oketani massage and acupressure pressure of GB-21 on milk production in post-Caesarea section mothers. The research method used is quantitative research with a quasi-experimental research design, one group pre-posttest design. The results showed that the pressure on the acupressure point of $G B-21$ was sufficient based on mother and baby indicators. The statistical test results showed differences in milk production before and after pressure at the acupressure point of Gb-12 (p-value $=0.000)$. In conclusion, oketani massage is more effective in increasing milk production in group $A$, post section caesarea mothers compared to group $B$, the pressure at the acupressure point Gb-21 from infant indicators.
\end{abstract}

Keywords: Gb-21 Acupressure, Breast Milk, Oketani Massage, Sectio Caesarea

\section{PENDAHULUAN}

Produksi ASI dipengaruhi oleh faktor hormonal (prolaktin dan oksitosin), asupan makanan, kondisi psikologis ibu, perawatan payudara, frekuensi menyusui, dan konsumsi obat /kontrasepsi hormonal (Arumsari et al., 2018). Salah satu pijat didaerah payudara adalah pijat oketani merupakan salah satu metode breast care yang tidak mengakibatkan rasa nyeri. Pijat oketani dapat merangsang kekuatan otot pectoralis sehingga dapat 
meningkatkan produksi ASI dan membuat payudara lebih lembut dan elastis (Jama \& Suherman, 2019).

Pijat oketani lebih efektif meningkatkan produksi ASI pada ibu post partum dibandingkan dengan teknik marmet, menyatakan bahwa terjadi peningkatan nilai pre test dan post test pada produksi ASI setelah diberikan pijat oketani. Ini menunjukan bahwa terjadi peningkatan produksi ASI yang signifikan dengan nilai $p$ value $=0,000$ sehingga pijat oketani efektif dalam meningkatkan produksi ASI (Astari \& Machmudah 2019).

Hasil penelitian Anderson et al., (2019) menunjukkan beberapa efek dari pijat oketani yaitu mengurangi nyeri pada payudara, meningkatkan pasokan ASI dan sebagai resolusi untuk saluran yang tersumbat, pembengkakan dan mastitis.

Akupresur umumnya digunakan di dalam ilmu kandungan atau kebidanan. Akupresur ini menggunakan tangan untuk menekan beberapa titik akupunktur pada tubuh. Akupresur mungkin dapat memulihkan dan menyeimbangkan energi tubuh untuk meningkatkan fungsi tubuh. Itu juga dapat mempengaruhi produksi prolaktin menjadi meningkatkan produksi ASI (Raras et al., 2016).

Teknik akupresur salah satu upaya yang dapat dilakukan untuk meningkatkan produksi ASI, teknik ini merupakan pemijatan dan stimulasi pada titik-titik tertentu di daerah tubuh (Khabibah \& Mukhoirotin, 2019) Stimulasi akupresur akan ditransmisikan ke sum-sum tulang belakang dan otak melalui saraf akson, sehingga terjadi rangsangan sinyal mengaktivasi Sistem Saraf Pusat (SSP) menyebabkan perubahan neurotransmitter, hormon prolaktin dan oksitosin, efek biomekanik, endhorpin dan sitokinin menimbulkan normalisasi dan efek keseimbangan pada Qi (Arumsari et al., 2018).

Dalam penelitian yang dilakukan oleh Saraung et al., (2017) di Puskesmas Ranotano Weru dengan total sampel 65 ibu postpartum didapatkan bahwa terapi akupresur efektif untuk meningkatkan produksi ASI pada ibu postpartum yang mengalami penurunan produksi ASI.

Jumlah total persalinan yang selalu bertambah dari tahun ketahun dalam 3 tahun terakhir, dari 3 tahun tersebut didapatkan bahwa pada tahun 2019 memiliki total persalinan yag tinggi dan total persalinan section caesarean yang tinggi juga di tahun tersebut. Dapat dilihat tingginya angka persalinan section caesarean yang dapat beresiko untuk terjadinya penundaan saat pemberian Inisiasi Menyusu Dini (IMD) atau bahkan penundaan pemberian ASI eksklusif karena ibu post section caesarean masih berfokus pada rasa nyeri setelah pembedahan (Badan Rumah Sakit Daerah Kabupaten Banggai Provinsi Sulawesi Tengah, 2020).

Banyak ditemukan ibu dengan post sectio caesarea dengan masalah pada payudara yaitu payudara bengkak, produksi ASI kurang sehingga bayi mereka diberikan susu formula, dan edukasi perawatan payudara diberikan namun tidak berjalan optimal. Penelitian tentang pijat oketani dan akupresur sudah pernah dilakukan, namun pada penelitian ini berfokus pada pijat oketani dan akupresur pada titik GB-21.

\section{METODE PENELITIAN}

Penelitian ini adalah penelitian quasi eksperimental dengan two-group pre-posttest design. Sampel dalam penelitian ini adalah ibu post sectio caesarea Di Badan Rumah Sakit Daerah Kabupaten Banggai Provinsi Sulawesi Tengah. Besar sampel dihitung dengan rumus feederer. Sampel dalam penelitian ini adalah 34 orang ibu post sectio caesarea di 
Badan Rumah Sakit Daerah Kabupaten Banggai Provinsi Sulawesi Tengah. Teknik pengambilan sampel pada penelitian ini menggunakan purposive sampling. Peneliti menerapkan kriteria inklusi dan ekslusi. Kriteria inklusi dalam penelitian ini yaitu ibu post sectio caesarea, ibu dengan produksi ASI kurang atau produksi ASI belum keluar, bersedia mengikuti penelitian, bayi tidak diberikan susu formula selama pengembilan data, bayi sehat dengan nilai APGAR lebih dari 7 pada menit pertama dan kelima, ibu tidak mengalami komplikasi post operasi, reflex hisap baik, rawat gabung, kondisi putting ibu normal, sedangkan kriteria eksklusi dalam penelitian ini adalah selama dalam masa intervensi klien tidak taat terhadap proses pemberian intervensi, bayi mengalami asfiksia, BBLR atau penyakit berbahaya lainnya, rawat terpisah, bayi diberikan susu formula salama masa intervensi.

Penelitian ini dilakukan dengan memperhatikan serta memperhatikan etika dalam melakukan penelitian meliputi prinsip-prinsip etika dan informed consent. Aplikasi pada responden kelompok A dan kelompok B sebelum diberikan inform consent peneliti memberikan penjelasan pada responden yang memenuhi kriteria inklusi tentang tujuan, manfaat, prosedur penelitian dan peran responden, kemudian peneliti memberikan kesempatan pada responden tersebut untuk menentukan bersedia atau tidaknya menjadi responden pada penelitian ini. Responden bersedia diminta untuk menandatangani pernyataan/inform consent dan lembar edukasi tujuan penelitian. Lembar infromed consent diberikan kepada responden untuk ditandatangani setelah diberikan penjelasan prosedur penelitian, keuntungan dan kerugian bagi responden serta manfaat dari penelitian. Instrumen yang digunakan pada penelitian ini adalah lembar observasi produksi ASI yang telah dilakukan uji validitas dan reliabilitas oleh peneliti sebelumnya.

Peneliti melakukan kegiatan selama 5 hari dengan intervensi selama 3 hari, tatap muka setiap hari 2 kali pagi dan sore, hari pertama dilakukan pre-test menggunakan lembar observasi produksi ASI kemudian dilakukan intervensi pijat oketani pada kelompok A dan intervensi tekanan pada titik akupresure $G B-21$ pada kelompok B pada hari ke 2,3 dan ke 4 dengan total 8 kali pertemuan setelah itu pada hari ke 5 dilakukan post test menggunakan lembar observasi produksi ASI.

\section{Hasil PENELITIAN}

\section{Analisa Univariat}

Tabel.1

Distribusi Responden Berdasarkan

Karakteristik Responden (N=34)

\begin{tabular}{|c|c|c|c|c|c|c|c|}
\hline \multirow{3}{*}{ Variabel } & \multicolumn{7}{|c|}{ Kelompok } \\
\hline & \multicolumn{2}{|c|}{ Pijat Oketani } & \multicolumn{2}{|c|}{$\begin{array}{c}\text { Tekanan Titik } \\
\text { Akupresure } \\
G b-21\end{array}$} & \multicolumn{2}{|c|}{ Total } & \multirow[t]{2}{*}{$\begin{array}{r}P \text { Value } \\
\text { Uji } \\
\text { Homogenitas }\end{array}$} \\
\hline & $\mathrm{N}$ & $\%$ & $\mathrm{~N}$ & $\%$ & $\mathrm{~N}$ & $\%$ & \\
\hline \multicolumn{8}{|l|}{ Usia } \\
\hline $\begin{array}{l}\text { 1. } \leq 20 \text { Tahun dan }>35 \\
\text { Tahun }\end{array}$ & 0 & 0 & 0 & 0 & 0 & 0 & 0,488 \\
\hline 2. 21-35 Tahun & 17 & 100,0 & 17 & 100,0 & 34 & 100,0 & \\
\hline
\end{tabular}




\begin{tabular}{lccccccc}
\hline Pendidikan & 3 & 17,6 & 2 & 11,8 & 5 & 14,7 & 0,348 \\
1. Rendah & 14 & 82,4 & 15 & 88,2 & 29 & 85,3 & \\
2. Tinggi & 13 & 76,5 & 13 & 76,5 & 26 & 76,5 & 1,000 \\
\hline Agama & 4 & 23,5 & 4 & 23,5 & 8 & 23,5 & \\
1. Islam & & & & & & & \\
2. Selain Islam & 13 & 76,5 & 11 & 64,7 & 24 & 70,6 & 0,153 \\
\hline Pekerjaan & 4 & 23,5 & 6 & 35,3 & 10 & 29,4 & \\
1. Tidak Bekerja & & & & & & & \\
2. Bekerja & 4 & 23,5 & 2 & 11,8 & 6 & 17,6 & 0,853 \\
\hline Suku & 0 & 0 & 1 & 5,9 & 1 & 2,9 & \\
1. Bugis & 5 & 29,4 & 3 & 17,6 & 8 & 23,5 & \\
2. Sunda & 6 & 35,3 & 7 & 41,2 & 13 & 38,2 & \\
3. Jawa & 0 & 0 & 1 & 5,9 & 1 & 2,9 & \\
4. Saluan & 2 & 11,8 & 3 & 17,6 & 5 & 14,7 & \\
5. Balantak & & & & & & & \\
6. Lainnya & & &
\end{tabular}

Berdasarkan tabel 1 diketahui bahwa seluruh responden berumur 21-35 tahun yaitu sebanyak 17 responden (100\%), mayoritas pendidikan responden adalah pendidikan tinggi yaitu sebanyak 14 responden $(85,3 \%)$, mayoritas agama responden adalah agama Islam yaitu sebanyak 13 responden (76,5\%), mayoritas pekerjaan responden adalah tidak bekerja yaitu sebanyak 13 responden (70,6 \%), mayoritas suku responden adalah saluan yaitu sebanyak 6 responden $(38,2 \%)$.

\section{Analisa Bivariat}

Tabel. 2

Perbedaan Rata-Rata Produksi ASI Ibu Post Sectio Caesarea pada Kelompok Pijat Oketani dan Kelompok Tekanan di Titik Akupresure Gb-21 dari Indikator Ibu $(\mathrm{n}=34)$

\begin{tabular}{|c|c|c|c|c|c|}
\hline \multirow[b]{2}{*}{ Variabel } & \multirow[t]{2}{*}{ Kelompok } & \multicolumn{3}{|c|}{ Produksi ASI } & \multirow[b]{2}{*}{$P$ Value } \\
\hline & & Mean & SD & $\mathrm{n}$ & \\
\hline \multirow{6}{*}{ Produksi ASI } & Kelompok Pijat Oketani & & & & \multirow{3}{*}{0,000} \\
\hline & Sebelum & 3,71 & 1,047 & 17 & \\
\hline & Setelah & 6,53 & 1,121 & 17 & \\
\hline & \multicolumn{4}{|c|}{ Kelompok Tekanan di Titik Akupresure $G b-21$} & \\
\hline & Sebelum & 4,12 & 0,993 & 17 & 0,000 \\
\hline & Setelah & 5,71 & 1,105 & 17 & \\
\hline
\end{tabular}

Berdasarkan kedua intervensi di atas dapat disimpulkan bahwa intervensi pijat oketani memiliki selisih paling besar dari pada intervensi tekanan di titik akupresure $G b$ 21, sehingga intervensi pijat oketani lebih memberikan pengaruh terhadap produksi ASI dari indikator ibu pada ibu post sectio caesarea 
Tabel. 4

Perbedaan Rata-Rata Produksi ASI pada Ibu Post Sectio Caesarea pada Kelompok Pijat Oketani dan Kelompok Tekanan di Titik Akupresure Gb-21 dari Indikator Bayi $(\mathrm{n}=34)$

\begin{tabular}{cccccc}
\hline & Kelompok & \multicolumn{4}{c}{ Produksi ASI } \\
\cline { 3 - 4 } Variabel & & Mean & SD & $\mathrm{N}$ & P Value \\
\hline Produksi ASI & Kelompok Pijat & Oketani & & & \multirow{2}{*}{0,000} \\
& Sebelum & 2,47 & 1,068 & 17 & \multirow{2}{*}{0,000} \\
& Setelah & 4,41 & 1,004 & 17 &
\end{tabular}

Kelompok Tekanan di Titik Akupresure Gb-21

\begin{tabular}{cllll} 
Sebelum & 3,06 & 0,966 & 17 & 0,000 \\
Setelah & 4,53 & 1,179 & 17 & \\
\hline
\end{tabular}

Berdasarkan kedua intervensi diatas dapat disimpulkan bahwa intervensi pijat oketani memiliki selisih paling besar dari pada intervensi tekanan di titik akupresure $G b-21$, sehingga intervensi pijat oketani lebih memberikan pengaruh terhadap produksi ASI dari indikator bayi pada ibu post sectio caesarea.

Tabel. 5

Perbedaan Efektifitas Produksi ASI pada Ibu Post Sectio Caesarea dari Indikator Bayi dan dari Indikator Ibu $(n=34)$

\begin{tabular}{llllll}
\hline $\begin{array}{c}\text { Variabel } \\
\text { Produksi ASI }\end{array}$ & \multicolumn{1}{c}{ Kelompok } & N & Mean & SD & P Value \\
\hline Indikator Bayi & Pijat Oketani & 17 & 4,41 & 1,004 & 0,756 \\
& $\begin{array}{l}\text { Pijat Tekanan di } \\
\text { Titik Akupressure } \\
\text { Gb-2l }\end{array}$ & 17 & 4,53 & 1,179 & \\
& Pijat Oketani & 17 & 6,53 & 1,125 & 0,039 \\
Indikator Ibu & Pijat Tekanan di & 17 & 5,71 & 1,105 & \\
& $\begin{array}{l}\text { Titik Akupressure } \\
\text { Gb-21 }\end{array}$ & & & & \\
\hline
\end{tabular}

Hasil statistik uji t tidak berpasangan (independent sample $t$-test) untuk nilai $p=0,039$ $(p<0,05)$, maka dapat ditarik kesimpulan ada perbedaan efektifitas pijat oketani dan kelompok tekanan di titik akupresure $G b-21$ terhadap produksi ASI pada ibu post sectio caesarea dari indikator ibu di Badan Rumah Sakit Daerah Kabupaten Banggai Provinsi Sulawesi Tengah. 


\section{PEMBAHASAN}

Hasil penelitian menunjukkan bahwa mayoritas usia responden di Badan Rumah Sakit Daerah Kabupaten Banggai Provinsi Sulawesi Tengah adalah 21-35 tahun yaitu sebanyak 34 orang $(100 \%)$, dimana usia tersebut tergolong usia dewasa awal. Ibu yang berumur 21-35 tahun sudah matang dan siap dalam hal jasmani dan sosial dalam mengahadapi kehamilan serta persalinan.

Kementrian Kesehaan Republik Indonesia (2017) menjelaskan bahwa usia 25-35 tahun adalah rentang usia produktif lebih mudah menerima informasi yang diperoleh mengenai ASI, sedangkan usia kurang dari 20 tahun dianggap belum matang secara fisik, mental dan psikologis dalam kehamilan dan persalinan. Usia lebih dari 35 tahun beresiko karena telah terjadinya penurunan fungsi alat reproduksi.

Hasil penelitian menunjukkan bahwa mayoritas pendidikan responden di Badan Rumah Sakit Daerah Kabupaten Banggai Provinsi Sulawesi Tengah adalah pendidikan tinggi yaitu sebanyak 29 orang $(85,3 \%)$. Orang yang memiliki dasar pendidikan yang tinggi lebih mudah mengerti dan memahami informasi yang diterimannya bila dibanding dengan orang yang berpendidikan lebih rendah. Hal ini sejalan dengan penelitian yang dilakukan oleh Saraung et al., (2017) menunjukkan bahwa produksi ASI pada ibu postpartum adalah mayoritas dengan pendidikan tinggi.

Hasil penelitian menunjukkan bahwa mayoritas pekerjaan responden di Badan Rumah Sakit Daerah Kabupaten Banggai Provinsi Sulawesi Tengah adalah tidak bekerja yaitu sebanyak 24 orang $(70,6 \%)$. Bekerja merupakan suatu kegiatan ekonomi yang dilakukan untuk memperoleh pendapatan. Bekerja tidak hanya dilakukan oleh laki-laki tetapi juga perempuan. Ibu yang tidak bekerja ketika masa menyusui mempunyai peluang lebih besar 0.396\% kali lebih besar untuk memberikan ASI (Bahriyah et al., 2017).

Hasil penelitian menyebutkan bahwa nilai rata-rata produksi ASI pada ibu post sectio caesarea sebelum diberikan intervensi pijat oketani berada pada produksi ASI kurang dan setelah diberikan intervensi nilai rata-rata responden berada pada produksi ASI cukup. Hasil uji dependent $t$ test menunjukkan bahwa ada perbedaan produksi ASI sebelum dan setelah diberikan intervensi pijat oketani $(p$ value $=0,000)$.

Dalam penelitian yang dilakukan oleh Astari (2019) tentang pijat oketani lebih efektif meningkatkan produksi ASI pada ibu post partum dibandingkan dengan teknik marmet, menyatakan bahwa terjadi peningkatan nilai pre test dan post test pada produksi ASI setelah diberikan pijat oketani. Ini menunjukan bahwa terjadi peningkatan produksi ASI yang signifikan dengan nilai $p$ value $=0,000$ sehingga pijat oketani efektif dalam meningkatkan produksi ASI.

Berdasarkan analisis peneliti bahwa pemberian inovasi pijat oketani efektif dalam melancarkan produksi ASI dan ekresi ASI karena pijat oketani merangsang otot-otot dada yang lebih besar untuk meningkatkan produksi ASI.

Hasil penelitian menyebutkan bahwa nilai rata-rata produksi ASI pada ibu post sectio caesarea berdasarkan indikator ibu dan bayi sebelum diberikan intervensi tekanan di titik akupresure $G b-21$ berada pada produksi ASI kurang dan setelah diberikan intervensi nilai rata-rata responden berada pada produksi ASI cukup. Hasil uji dependent $t$ test menunjukkan bahwa ada perbedaan produksi ASI sebelum dan setelah diberikan tekanan di titik akupresure $G b-12$ ( $p$ value $=0,000)$. 
Penelitian yang dilakukan oleh Khabibah \& Mukhoirotin (2019) bahwa produksi ASI pada ibu postpartum di RSUD Jombang dengan total sampel 24 ibu postpartum, setelah diberikan intervensi terapi akupresur dan pijat oksitosin didapatkan nilai $\mathrm{p}=0.000(\mathrm{p}<0.05)$, artinya ada pengaruh akupresur dan pijat oksitosin terhadap produksi ASI pada ibu postpartum. Hal ini sejalan dengan penelitian sebelumnya yang menunjukan bahwa ada pengaruh akupresur terhadap produksi ASI ibu postpartum di Klinik Mujahidin Bantul dengan indikator berat badan bayi. Akupresur dapat dijadikan alternatif untuk meningkatkan produksi ASI pada ibu postpartum (Djanah \& Muslihatun, 2017).

Berdasarkan analisis peneliti bahwa pemberian inovasi tekanan dititik akupresur $G b$ 21 efektif dalam melancarkan produksi ASI karena acupressure point for lactation dapat diberikan melalui titik meridian sesuai organ yang akan dituju dan dapat juga membantu mengurangi rasa ketidaknyamanan sehingga memicu refleks let down dan meningkatkan kadar prolaktin dan hormon oksitosin. Selain itu akupresur juga mampu merangsang pelepasan endorphin, memblokir reseptor rasa sakit, menstimulasi pelepasan hormon oksitosin dan dapat mempengaruhi produksi prolaktin yang dapat meningkatkan produksi ASI (Mahmudah et al., 2019).

Hasil statistik uji t tidak berpasangan (independent sample t-test), menunjukkan bahwa ada perbedaan efektifitas pijat oketani dan kelompok tekanan di titik akupresure $G b$ 21 terhadap produksi ASI pada ibu post sectio caesarea dari indikator ibu ( $p$ value $=0,039$ $>0,05)$.

Berdasarkan analisis peneliti bahwa indikator dari faktor ibu ini yang dilihat adalah melalui ketegangan payudara, let down refleks bekerja dengan baik, hal ini menandakan kerja dari hormon oksitosin yang menyebabkan terjadinya let down refleks ini juga bekerja dengan baik. Salah satu yang menyebabkan kerja hormon oksitosin baik adalah karena adanya rangsangan dari bayi serta ibu yang relaks, yang salah satu caranya adalah dengan perangsangan melalui pijat oketani.

Faktor lain yang juga mempengaruhi kerja dari hormon oksitosin adalah kondisi psikologis ibu, ibu post seksio sesarea yang langsung menyusui bayinya, dapat mengatasi masalah-masalah dalam menyusui membuat ibu lebih relaks membuat kerja hormon oksitosin semakin lancar. Hal ini sejalan dengan penelitian yang dilakukan oleh (Susilawati \& Halim, 2018) bahwa terdapat perbedaan antara produksi ASI sebelum dan sesudah dilakukan intervensi akupresur yang meningkat menjadi 46,8\%. Akupresur merupakan salah satu terapi nonfarmakologis untuk merangsang pengeluaran hormon endorphin, prolaktin dan oksitosin.

\section{SIMPULAN}

Mayoritas responden berusia 21-35, pendidikan tinggi, agama islam, pekerjaan tidak bekerja, dan suku saluan. Hasil penelitian pada kelompok intervensi menunjukkan adanya perbedaan produksi ASI sebelum dan sesudah dilakukan intervensi pijat oketani pada kelompok A dan tekanan di titik akupresure $G b-21$ pada kelompok B. Pijat oketani lebih efektif untuk meningkat produksi ASI pada kelompok A ibu post sectio caesarea dibandingkan kelompok B tekanan di titik akupresure $G b-21$ dari indikator bayi. 
Pijat oketani lebih efektif untuk meningkat produksi ASI pada kelompok A ibu post sectio caesarea dibandingkan kelompok B tekanan di titik akupresure $G b-21$ dari indikator ibu. Ada perbedaan efektifitas pijat oketani pada kelompok A dan kelompok B tekanan di titik akupresure $G b-21$ terhadap produksi ASI pada ibu post sectio caesarea dari indikator Ibudi Badan Rumah Sakit Daerah Kabupaten Banggai Provinsi Sulawesi Tengah.

\section{SARAN}

Rekomendasi untuk menambah variabel baru terkait tekanan di titik akupresure $G b$ 21 untuk meningkatkan produksi ASI terutama pada ibu post sectio caesarea.

\section{DAFTAR PUSTAKA}

Anderson, L., Kynoch, K., Kildea, S., \& Lee, N. (2019). Effectiveness of Breast Massage for The Treatment of Women with Breastfeeding Problems: A Systematic Review. JBI Database of Systematic Reviews and Implementation Reports, 17(8), 1668-1694. https://doi.org/10.11124/JBISRIR-2017-003932

Arumsari D R, Indrawan I W A, Wahyuni E S. (2018). The Combination of Acupressure and Affirmation Relaxation as an Alternative Method to Increase Breast Milk Production and Breastfeeding Self-efficacy. Research Journal of Life Science, 5(1), 66-76. DOI: 10.21776/ub.rjls.2018.005.01.7

Astari, A. D., \& Machmudah, M. (2019. Pijat Oketani Lebih Efektif Meningkatkan Produksi ASI pada Ibu PostPartum Dibandingkan dengan Teknik Marmet. Prosiding Seminar Nasional Mahasiswa Unimus, 2, 242-248. https://prosiding.unimus.ac.id/index.php/mahasiswa/article/view/468

Bahriyah, F., Putri, M., \& Jaelani, A. K. (2017). Hubungan pekerjaan ibu terhadap pemberian ASI eksklusif pada bayi di wilayah kerja Puskesmas Sipayung. Jurnal Endurance: kajian Ilmiah Problema Kesehatan, 2(2), 113-118. http://ejournal.kopertis10.or.id/index.php/endurance/article/view/1699

Djanah, N., \& Muslihatun, W. N. (2015). Akupresur terhadap Produksi ASI pada Ibu $\begin{array}{llll}\text { Postpartum. } & \text { Jurnal } & \text { photon, } & \text { i }\end{array}$ http://ejurnal.umri.ac.id/idex.php/photon/article/view/544

Jama, F., \& Suhermi, S. (2019). Efektifitas Pijat Oketani terhadap Bendungan ASI pada Ibu Post Partum di RSB.Masyita Makassar. Journal Of Islamic Nursing, 4(1), 78. DOI: 10.24252/join.v4i1.7931

Kemenkes RI, (2017). Profil Kesehatan Indonesia 2016. Keputusan Menteri Kesehatan Republik Indonesia. Jakarta

Khabibah, L., Mukhoiritin, M. (2019). Pengaruh terapi akupresur dan pijat oksitosin terhadap peningkatan produksi ASI pada ibu postpartum di RSUD Jombang. Jurnal Edunursing, $3(2)$, 68-77. http://journal.unipdu.ac.id:8080/index.php/edunursing/article/view/1848

Mahmudah, M., Khayati, N., Widodo, S., Hapsari, E. D., \& Haryanti, F. (2018). Increasing Oxytocin Hormone Levels in Postpartum Mothers Receiving Oketani Massage and Pressure in the GB-21 Acupressure Point. International Journal of Advancement in Life Sciences Research, 2(1), 22-27. https://doi.org/10.31632/ijalsr.2018v02i01.004. 
Raras, N., Suwondo, A., Wahyuni, S., \& Laska, Y. (2016). Different Amount of Prolactin Hormone Before and After Acupressure-Aromatherapy Combination Technique in Lactation: Epidemiological-Clinic Study on Post Partum. ASEAN/Asian Academic, 332-338. http://aasic.org/proc/aasic/article/view/194

Riskesdas. (2018). Kementerian Kesehatan Republik Indonesia. Badan Penelitian dan Pengembangan Masyarakat.

Rumah Sakit Daerah Provinsi Sulawesi Tengah. (2020). Data Ruang Perawatan Kebidanan tahun 2017-2019.

Saraung, M W., Rompas, S., \& Bataha, Y. B. (2017). Analisis Faktor-Faktor yang Berhubungan denga Produksi ASI pada Ibu Postpartum di Puskesmas Ranotana Weru. Je-Jurnal keperawatan (e-Kp), 5(2), 1-8. https://ejournal.unsrat.ac.id/index

Susilawati, F., \& Halim A. (2018). Pengaruh Pemberian Aroma Terapi Rose dan Akupresur pada Ibu Menyusui Pasca Saesar Caesarea terhadap Kecukupan ASI pada Bayi. Jurnal Ilmiah Keperawatan Sai Betik, 14 (1), 59-67. http://www.ejurnal.poltekestjk.ac.id/index.php/JKEP/article/view/1009 